Federal Reserve Bank of Dallas

Globalization and Monetary Policy Institute

Working Paper No. 264

http://www.dallasfed.org/assets/documents/institute/wpapers/2016/0264.pdf

\title{
The Implications of Liquidity Expansion in China for the US Dollar ${ }^{*}$
}

\author{
Wensheng Kang \\ Kent State University \\ Ronald A. Ratti \\ Western Sydney University \\ Joaquin L. Vespignani \\ University of Tasmania
}

January 2016

\begin{abstract}
The value of the US dollar is of major importance to the world economy. Global liquidity has grown sharply in recent years with growing importance of China's money supply to global liquidity. We develop out-of-sample forecasts of the US dollar exchange rate value using US and non-US global data on inflation, output, interest rates, and liquidity on the US, China and non-US/non-China liquidity. Monetary model forecasts significantly outperform a random walk forecast in terms of MSFE at horizons over 12 to 30 months ahead. A monetary model with sticky prices performs best. Rolling sample analysis indicates changes over time in the influence of variables in forecasting the US dollar. China's liquidity has a distinct, significant and changing influence on the US dollar exchange rate. Post global financial crisis, increases in the growth rate in China's M2 forecast a significantly higher value for the US dollar 12 months and 18 months ahead and significantly lower values for the US dollar 24 and 30 months.
\end{abstract}

JEL codes: E41, E51, F31, F41

\footnotetext{
* Wensheng Kang, Kent State University, Kent, OH 44242. wkang3@kent.edu. 330-308-7414. Ronald A. Ratti, School of Business, University of Western Sydney, Australia. r.ratti@westernsydney.edu.au. 61-29685-9346. Joaquin L. Vespignani, University of Tasmania, Tasmanian School of Business and Economics, Australia. joaquin.vespignani@utas.edu.au. 61-3-62262825. The views in this paper are those of the authors and do not necessarily reflect the views of the Federal Reserve Bank of Dallas or the Federal Reserve System.
} 


\section{The Implications of Liquidity Expansion in China for the US Dollar}

\section{Introduction}

Much recent research has concentrated on the influence of global liquidity on commodity, goods and asset prices. Beckman et al. (2014) demonstrate that global liquidity factors influence commodity prices. D’Agostino and Surico (2009) show that change in global liquidity has predictive power for the US inflation rate. Belke et al. (2010) document that increases in global liquidity since 2001 raises the price of assets inflexible in supply. Ratti and Vespignani (2015) find that unanticipated increase in emerging countries' liquidity has a much greater influence on commodity prices than does that of developed economies.

In this paper we examine the influence of liquidity increases on the US dollar exchange rate value. Our focus is on the value of the US dollar relative to the currencies of the rest of the world, and not on a bilateral exchange rate between the US currency and that of another country. The value of the US dollar relative to the world's other currencies is of major importance to the US and the rest of the world. Emerging economies have companies with large US dollar denominated debt. The US dollar denomination is a high fraction in international bonds (Goldberg (2011) and Lo Duca et al. (2014)). Bruno and Shin (2015) and McCauley et al. (2015) associate appreciation of the US dollar with a decrease in bank capital flows and effective monetary tightening across the world.

The influence of liquidity increases on the US dollar exchange rate is examined within the context of monetary models of exchange rates. ${ }^{1}$ These models suggest that the influence on the US dollar exchange rate of liquidity outside the US is to be distinguished from that of US liquidity. In assessing the impact of liquidity on the US dollar exchange rate we find it is useful to identify the origins of the changes in global liquidity. China, in

\footnotetext{
${ }^{1}$ Sarno and Taylor (2002) provide an authoritative review of the economics literature on exchange rates. Rossi appraisals the literature on forecasting exchange rates. Chinn (2012) reviews macroeconomic methods in modelling the determinants of exchange rates. Aizenman et al. (2009) review work that considers the connections between global liquidity defined in terms of international reserves, global imbalances and reserve management.
} 
particular, has become an important provider of liquidity in recent years. The growing importance of China's money aggregates for global liquidity is illustrated in Figure 1a. In Figure 1a the log of M2 money supplies expressed in U.S. dollars in China, US, Euro area, and Japan over 1996:01-2013:12 are presented. By August 2009, M2 in China exceeds that in the U.S., the Euro area, and in Japan. China’s nominal M2 (in USD) increased on average by 19.6\% per year from 1996 to $2013 .^{2}$

Our work examining the forecast performance of monetary models of the overall US dollar exchange rate is facilitated by the availability of non-US global data in a new database, Database of Global Economic Indicators (DGEI), Federal Reserve Bank of Dallas. We develop out-of-sample forecasts of the US dollar exchange rate value using US and non-US global data on inflation, output, interest rates, and liquidity in the US, China, and the nonUS/non-China rest of the world. A monetary model with sticky prices framework significantly outperforms a random walk model in terms of out-of-sample forecasts at horizons of 12 to 30 months ahead. The best forecast from the model for the US dollar exchange rate is 25 months ahead. Monetary models with flexible prices also achieve statistically significant lower mean square forecast errors (MSFE) than a random walk model at horizons of 12 to 30 months ahead. The monetary model with sticky prices generates much lower MSFE than the monetary models with flexible prices.

Rolling sample analysis indicates changes over time in the influence of variables in forecasting the US dollar exchange rate. China's liquidity does have a distinct, significant and changing influence on the US dollar exchange rate compared to non-US/non-China global liquidity. It is difficult to tie results on the changing sign of the coefficient for the effect of China's liquidity growth on the US dollar exchange rate to the timing of China's changing exchange rate policy. Post global financial crisis, increases in the growth rate in China's M2

\footnotetext{
${ }^{2}$ The behaviour of China's nominal GDP is also strongly upward over the period, increasing on average (in U.S. dollars) by $15 \%$ per year.
} 
forecast a significantly higher value for the US dollar 12 months and 18 months later and significantly lower values for the US dollar 24 and 30 months later. The largest impacts, and the greatest divergence of the effect of China's liquidity on the future value of the US dollar across forecast horizons, occur in the post financial crises period. In forecasting US terms of trade, China's M2 growth forecast a significantly higher value 18 months later and a significantly lower value 30 months later from July 2007 onwards. Differentials between non-US global and US values for inflation, output, and interest rate are highly statistically significant in forecasting the US dollar exchange rate.

Section 2 reviews China's exchange rate policy. Monetary models for the US dollar exchange rate are presented in Section 3.1 and data and variables (US and non-US) are defined in Section 3.2. Section 4 provides empirical results on out-of-sample US dollar exchange rate prediction. Robustness of results is examined in Section 5. Section 6 concludes.

\section{China's Exchange Rate Policy}

The exchange rate policy of China is important in assessing the impact of China's liquidity on the US dollar. China tied its currency to the value of the US dollar from the Asian crisis in the late 1990s until July 2005. After July 21, 2005 the value of renminbi is determined with regard to a basket of currencies in which the dollar is of major importance. As illustrated in Figure 1b the value of the renminbi gradually increased versus the US dollar. Over three years following July 2005, the renminbi strengthened by about $21 \%$ versus the US dollar. Over an extended period from August 2008 to June 2010 the renminbi/dollar rate did not vary. ${ }^{3}$ In June 2010, China's exchange rate became more flexible and gradually appreciated at about 5\% per year. These developments are illustrated in Figure 1b.

\footnotetext{
${ }^{3}$ Frankel (2009) provides a detailed examination of China's exchange rate regime. Dekle and Ungor (2013) note that the change in China's exchange rate policy in August 2008 was due China's export sector being under pressure following the US subprime crisis and the decline in world trade.
} 
A rise in China's liquidity facilitates domestic growth and increases demand for imports and foreign interest in investing in China. The currencies of the countries supplying imports to China experience upward pressure as will the prices of the imported goods including commodities. Foreign investment flows also influences bilateral exchange rates. As these effects work their way through the financial markets, China intervenes in the foreign exchange market to stabilize the pegged exchange rate. The scale and mix of foreign currencies sold by China in the foreign exchange market will depend on the weights assigned to currencies in the reference basket of major currencies (against which the renminbi is allowed to float within a narrow margin).

The effects on the U.S. dollar foreign exchange rate overall of monetary expansion in China depends on the above influences and there are likely to be consequences for the US dollar beyond that which would be expected upon monetary expansion in a small open economy operating a US dollar peg (with or without capital controls). Fratzscher and Mehl (2014) present evidence of a tri-polar global economy with the renminbi affecting exchange rate and monetary policies in Asia, distinctly so since the global financial crisis. China has achieved a size in terms of GDP on a PPP basis and level of monetary aggregates and in other dimensions that liquidity expansion in China might have consequences for the US dollar exchange rate. ${ }^{4}$ Cai et al. (2012) and Fang et al. (2012) find that since 2005 the renminbi/U.S. dollar value has overshadowed the renminbi exchange rate versus other currencies in shaping the overall value of the renminbi. ${ }^{5}$ In contrast, Frankel (2009) argues that by mid-2007 the value of the euro had become an important focus in China's exchange rate peg and that the

\footnotetext{
${ }^{4}$ The IMF estimates that on a PPP basis China's GDP exceeds that in the US by about $4.30 \%$ in 2014. China's M2 exceeds that in the US by about 65\% in December 2013 (Federal Reserve Bank of St. Louis statistics).

${ }^{5}$ A large literature has developed examining the increased economic influence of China on other countries. Chinn (2009) summarizes several papers examining the impact of China on the global economy including that of being a large net saver. Thomas et al. (2009) argue that China's rapid growth has had major effects on the configuration of global trade. Granville et al. (2011) examine the amount of price and exchange rate interaction between the G3 and China.
} 
assumption of exclusive focus on the value of the dollar in China's exchange rate management would not be correct. ${ }^{6}$

\section{Methodology}

\subsection{Monetary models of the exchange rate}

In this paper we focus on predicting the value of the US dollar. The value of the US dollar will be defined as the trade weighted US dollar index. The structural model utilized to predict the value of the US dollar encompasses leading monetary models of exchange rate determination. We aim at tracking over the long-term the trade weighted US dollar index with a simple reduced-form model. We construct $h$ month ahead out-of-sample forecasts of the trade weighted US dollar index. We assess the effects on $h$ month ahead trade weighted US dollar index of Chinese, US, and global liquidity expansion on the US dollar value by postulating the following encompassing model:

$$
T W I_{t+h}=\beta_{0}+\beta_{1} T W I_{t}+\beta_{2} M_{t}^{\text {China }}+\beta_{3} M_{t}^{U S}+\beta_{4} M_{t}^{G l o b a l}+\beta_{5} X_{t}+\varepsilon_{t},
$$

where $T W I_{t+h}$ is the $h$ month ahead growth rate of the trade weighted US dollar index $\left(T W I_{t}\right)$, $M_{t}^{\text {China }}$ is the Chinese M2 growth rate, $M_{t}^{U S}$ is the US M2 growth rate, $M_{t}^{\text {Global }}$ is the growth rate in non-China/non-US monetary aggregates, $X_{t}$ is a vector of relevant US and non-US differentials in interest rate, inflation and output variables, and $\beta_{5}$ is a vector of coefficients.

The model in equation (1) is associated with a particular monetary model according to the variables included in $X_{t}$ in line with the terminology adopted in Rossi (2013) for the main

\footnotetext{
${ }^{6}$ The appropriate measurement of China's exchange rate and of effects of China's exchange rate on trade flows have also been topics of research. Whalley and Wang (2011) show that the effect on trade flows of Renminbi appreciation can be substantial. Cheung et al. (2015) investigate the effect of the bilateral real exchange rate for US-China trade flows and find the effect to be enhanced when the exchange rate is measured as the deviation from equilibrium values
} 
predictors used for out-of-sample exchange rate forecasting. The monetary models are as follows. ${ }^{7}$

Monetary model with sticky prices (Dornbusch-Frankel model):

$$
X_{t}=\left(i_{t}^{*}-i_{t}^{U S}, \pi_{t}^{*}-\pi_{t}^{U S}, y_{t}^{*}-y_{t}^{U S}\right)
$$

Monetary model with flexible prices 1:

$$
X_{t}=\left(i_{t}^{*}-i_{t}^{U S}, y_{t}^{*}-y_{t}^{U S}\right) \text {, }
$$

Monetary model with flexible prices 2:

$$
X_{t}=\left(y_{t}^{*}-y_{t}^{U S}\right) \text {, }
$$

where $i_{t}^{*}, \pi_{t}^{*}$, and $y_{t}^{*}$ denote non-US global interest rate, inflation rate and output, and $i_{t}^{U S}, \pi_{t}^{U S}$, and $y_{t}^{U S}$ denote US interest rate, inflation rate and output.

We utilize the last 12-month moving average of the annual growth rates of monthly data for all the variables. The moving average is commonly used with time-series data to smooth out short-term fluctuations and highlight longer-term trends or cycles (see Stock and Watson (2007) for forecasting inflation, Holt (2004) and Engel (2015) for the exchange rate). A criticism is that the moving-average will be auto-correlated, even if the original series is not auto-correlated. Thus, using the moving-average as a dependent variable is a potential violation of the subsequent causal model (that is to show a spurious causal relationship) in the short-term forecasting model. We include the lag variable $T W I_{t}$ and consider its forecasting beyond the moving-average period 12, which is $T W I_{t+h}$, where $h>12$, in order to mitigate the serial correlation issue. The advantage is to smooth out short-term fluctuations and highlight longer-term trends or cycles. It is superior to the mean model in adapting to the cyclical pattern and is superior to the random walk model in not being too sensitive to random shocks from one period to the next. Data averaging is adopted in time-series models

\footnotetext{
7 Greater detail on these models can be found in Bilson (1978, 1979), Frenkel (1976), Dornbusch (1976), Frankel (1979, 1981), and Meese and Rogoff (1983).
} 
generating long-term predictions when seasonality in data might be a problem. To overcome seasonality in quarterly data, Engel et al. (2015) average data over four quarters in models forecasting bilateral exchange rates.

\subsection{Data and variables}

We identify for the US and for the non-US rest of the world, variables relevant to monetary models of US dollar exchange rate determination. The non-US and US interest rate, inflation rate and output variables are from Database from Global Economic Indicators (DGEI), Federal Reserve Bank of Dallas. ${ }^{8}$ In DGEI, weights (based on shares of world GDP (PPP)) are applied to the official/policy interest rates in levels and are applied to headline price indexes and output indices in growth rates to construct indices representing the G40 economies (excluding the U.S.). In 2012 on a GDP PPP basis, the G40 economies account for around $86 \%$ of global GDP (with the U.S. accounting for 19\% of global GDP). The non-US part of the global economy is taken to be the 19 largest non-US advanced economies and the 20 largest emerging economies enclosed within the G40. The headline price indexes and output indices are for consumer prices and industrial production.

The trade weighted US dollar index and monetary aggregate data are from FRED, Federal Reserve Bank of St. Louis ${ }^{9}$. The monetary variables are the growth rates in US dollar M2 for the US, China and the rest of the world. The (non-China/non-US) global liquidity is measured by the annual growth rate of a broad monthly monetary aggregate constructed for the Euro area, UK, Japan, Brazil, Russia and India. The global monetary aggregate is based on M4 for the UK, L2 for India, and M2 for the other economies.

The annual growth rates of monthly data of TWI and six fundamental variables in our model over January 1997 to December 2013 are drawn in Figure 2. Note the large

\footnotetext{
${ }^{8}$ The DGEI data was first released at the end of 2013 by the Globalization and Monetary Policy Institute at the Federal Reserve Bank of Dallas and is available at http://www.dallasfed.org/institute/dgei/index.cfm. For more details about this database construction, please see Grossman et al. (2013).

${ }^{9}$ The data is available at Federal Reserve Bank of St. Louis https://research.stlouisfed.org/fred2/.
} 
fluctuations in TWI and the monetary variables around the Global financial crisis in 20082009. The TWI annual growth rate drops to $-9.73 \%$ and $-12.77 \%$ and China's money growth achieves 30.27\% and 29.79\% in June 2008 and in April 2009. US money growth rate reaches a peak of $10.54 \%$ in January 2009 and is followed by a sharp decrease in the TWI starting in April 2009. When non-US/non-China money growth climbs to the highest value of $10.41 \%$ in February 2009, the TWI reaches the highest 19.43\% in March 2009. These observations are indicative that a decrease in TWI is likely associated with an increase in the growth of money in China and in the US and with a decrease in the growth of money in the non-China/non-US global economy.

\section{Empirical Result}

\subsection{Out-of-sample exchange rate forecasting}

We run our regression (1) over the sample 1999M1-2013M12. The MSFE is the metric for evaluating the forecast accuracy and for specifying the optimal forecast horizons in the model:

$$
\operatorname{MSFE}_{t_{1}}^{t_{2}}(h)=\frac{1}{t_{2}-t_{1}+1} \sum_{t=t_{1}}^{t_{2}}\left(T W I_{t+h \mid t}-T W I_{t+h}\right)^{2}
$$

where $T W I_{t+h \mid t}$ is the forecast of $T W I_{t+h}$ from Equation (1), $h$ is the month ahead forecast of the trade weighted US dollar index, and the summation of squared forecast errors runs over $1999 M 1+h \leq t_{1} \leq t_{2} \leq 2013 M 12$. The rolling sample analysis estimates Equation (1) using 55-month rolling samples starting in July 2005. The summation of squared forecast errors in Equation (2) runs over the sample 2005M7 $+h \leq t_{1} \leq t_{2} \leq 2013 M 12$.

Table 1 reports MSFE from estimating the regression in Equation (1) for different monetary models at different horizons, and for comparison, MSFE from a random walk forecast at different horizons. The MSFE of the monetary models model are lower than that of the random walk at all forecast horizons. To assess the significance of the out-of-sample 
forecasting ability of the monetary models compared to the random walk model, we utilize the DM-statistics proposed by Diebold and Mariano (1995). ${ }^{10}$ The MSFE of the monetary models model are significantly lower than that of the random walk at forecast horizons from 12 to 30 months. The MSFE is lower for the monetary model with sticky prices than for the monetary models with flexible prices at all forecast horizons. For the monetary model with sticky prices in Equation (1) the lowest MSFE is with the forecast horizon at 25-month ahead. The monetary model with sticky prices in which differentials between the US and non-US global economy in interest rate, inflation, and output influence the out-of-sample forecasts of the US dollar exchange rate is our preferred model.

\subsection{Estimation of the basic model over full sample}

Estimation of the monetary model with sticky prices version of Equation (1) with $h=25$ months over the full sample appears in column 1 of Table 2 . Adjusted $\mathrm{R}^{2}$ is 0.848 in column 1. We choose to report the version of Equation (1) with $h=25$ since this version of the estimated equation has the lowest RMSE and lowest $\mathrm{MSFE}^{\text {Stickey }} / \mathrm{MSFE}^{\mathrm{RW}}$ in Table 1. Increases in M2 growth in China and in the US both significantly reduce the growth in the trade weighted US dollar 25 months later. The latter result is in line with the theory that domestic monetary expansion devalues the currency. The result that increases in M2 growth in China lowers the US dollar 25 months is explained by the pegged exchange rate policy of China over most of the period of analysis. Increases in growth in non-US/non China global liquidity has a positive coefficient and statistically significantly affects the US dollar. The coefficients of the variables M2 growth in China and non-US/non China global liquidity are significantly different from one another.

\footnotetext{
${ }^{10}$ Note that we can use Diebold and Mariano (1995) for testing the null hypothesis of equal predictive ability at the estimated in-sample parameter values even though our models are nested. Another testing method such as Clark and McCraken (2015) concerns forecast losses that are evaluated at the population parameter values. The discussion is in Giacomini and Rossi (2010).
} 
In column 1 of Table 2, the coefficient of the inflation differential variable is 6.411 and is highly statistically significant. This implies that a rise in annual inflation outside the US is associated with a disproportionate appreciation in the US dollar 25 months later. In column 1 , the lagged dependent variable is highly statistically significant and has a negative coefficient given by -0.625 . This implies that a current rise in the US dollar will be reflected in a lower appreciation of the U.S. dollar in the future. The interest rate differential variable has a statistically significantly negative coefficient. A rise in non-US interest rates is linked with a lower U.S. dollar appreciation in the future. These results are all consistent with established exchange rate theories. The differential in growth rates in industrial production in the non-US world and in the US has a positive but nonsignificant coefficient value 0.203.

In column 6 of Table 2, the variables capturing differentials in interest rates, inflation and output between the non-US world and the US do not appear. The result is a collapse in adjusted $\mathrm{R}^{2}$ from 0.848 in column 1 to 0.435 . This implies that inclusion of the differentials in interest rates, inflation and output between the US and the rest of the world is essential in the forecasting of the US dollar.

In Columns 2 through 5 of Table 2 the effects of variations in the definitions of the liquidity variables are considered. In column 2, the liquidity variables are growth in US M2 and growth in non-US global liquidity (inclusive of China's liquidity). The former variable has a negative impact and the latter has a positive impact. Both the coefficient values and the t-statistics in absolute values are bolstered, in the sense that the effect of China's liquidity is absorbed by the two variables. In column 3, the only liquidity variable is growth in global liquidity (inclusive of US and China liquidity growth) and this variable remains a statistically significantly positive coefficient. These results show that the effect of China's liquidity is different from that of non-US global liquidity and should be examined separately. In column 4, growth in China's M2 is the only liquidity variable with a negative significant coefficient 
similar to that in column 1 . In column 5 , growth in non-US/non-China global liquidity is dropped from the regression, leaving the coefficients for growth in China M2 and growth in US M2 not greatly changed from the result in column 1. The model in Equation 1, with estimation result for the full sample in column 1 of Table 2, has the highest adjusted $\mathrm{R}^{2}$ and the lowest MSFE of the models on Table 2.

Estimation of the monetary models with flexible price versions 1 and 2 of Equation (1) with $h=25$ months over the full sample appear in columns 7 and 8 of Table 2. Adjusted $\mathrm{R}^{2}$ of these models at 0.579 and 0.576 are far lower than the 0.848 in column 1 for the monetary model with sticky prices. The monetary model with sticky prices dominates the monetary models with flexible prices in terms of Adjusted $\mathrm{R}^{2}$ and in terms of out-of-sample forecasting performance.

\subsection{Subsample result and instability issue}

Our full sample result in Table 2 presents a negative effect of China’s liquidity growth on US dollar exchange rate value. However, these results rely on the assumption of the stability of the estimated parameters in the model over time. We now investigate the timevariability of the coefficients in the model. As a preliminary step, we report subsample estimates for the monetary model with sticky prices in Table 3. The break in the sample is given by the change in the fixed peg for the exchange by China in June 2005. In sample over 1999M1-2005M6 Chinese money growth has a statistically significantly positive coefficient, whereas over 2005M7-2013M12 the coefficient is statistically significantly negative. These results suggest that the changing sign of the coefficient for the effect of China's liquidity growth on the US dollar exchange rate may be associated with the timing of changes in China’s exchange rate policy.

\subsection{Rolling sample analysis}


To assess the extent and nature of parameter instability issues of the forecast starting in July 2005, a rolling sample analysis is followed. We estimate Equation (1) using 55-month rolling samples. The first estimation sample uses data over 1999M1-2003M7, the second sample uses data over 1999M2-2003M8, etc., with each subsequent sample adding one new month and dropping the first month of the data in the preceding sample. The out-of-sample forecasting period begins in July 2005 and ends in December 2013.

\subsubsection{The coefficient estimates of Chinese money growth at 12, 18, 24, 30-month ahead forecast horizons}

Figure 3a shows the coefficient estimates of Chinese M2 growth at the 12, 18, 24, and 30-month ahead forecast horizons of trade-weighted US dollar exchange rate. The coefficient estimate of the effect of Chinese M2 growth $\left(\beta_{2}\right.$ in Equation (1)) for the 12 month ahead forecast labeled November 2011 in Figure 3a, for example, is for the forecasted value of WTI in November 2012. One standard deviation error bands appear around the parameter estimate.

The results in Figure 3a imply changing impact of growth in China’s M2 on TWI at all forecast horizons over time. In Figure 3a, the estimate of $\beta_{2}$ for the 12-month ahead forecast of WTI is negative and statistically significant from July 2004 to August 2008, and positive and statistically significant after November 2008. For the 18-month ahead forecast, the time periods during which statistical significance for the estimate of $\beta_{2}$ hold narrows. For the 24-month ahead forecast, the estimates of $\beta_{2}$ have changed significantly. In Figure 3a, the estimate of $\beta_{2}$ for the 24-month ahead forecast of WTI is negative and statistically significant after November 2009.

Post global financial crisis, increases in the growth rate in China's M2 forecast a significantly higher value for the US dollar 12 months and 18 months later (indefinitely for the 12 month forecast and for the 18 month forecast at least until April 2011), and significantly lower values for the US dollar 24 and 30 months later. In Figure 3b the 
estimates of $\beta_{2}$ for $12,18,24$, and 30 -month ahead forecast horizons appear together. The estimates of $\beta_{2}$ change over time for a given each forecast horizon with the greatest divergence estimates of $\beta_{2}$ across forecast horizon occurring with forecasts made from late 2009 to early 2011.

It is difficult to tie these results, on the changing sign of the coefficient for the effect of China's M2 growth on TWI, closely to the timing of China's fixed exchange rate policy in terms of the China renminbi/US dollar in the pre-2005M7 and 2008M8-2010M6 periods. The 2008M8-2010M6 period may be linked with increases in China's M2 predicting increases in TWI 12 months later and decreases in TWI 24 months later post global financial crisis.

\subsubsection{The coefficient estimates of non-US/non-China global money growth at $12,18,24$, 30-month ahead forecast horizons}

Figures 4a-4b show the coefficient estimates of non-US/non-China global money growth at the $12,18,24$, and 30 -month ahead forecast horizons of trade-weighted US dollar exchange rate. Before mid-2006, at the 12, 18, 24, and 30-month ahead forecast horizons of trade-weighted US dollar exchange rate the effects of China’s M2 are positive and bunched close together, with the effect at 12 months ahead being larger than the effect at 30 months ahead. The coefficient estimate $\left(\beta_{4}\right.$ in Equation (1)) of non-US/non-China M2 growth is statistically significantly positive before January 2009 for the 12 month ahead forecast and over the sample for the 18 month ahead forecast. This coefficient estimate is statistically significantly negative at most points of time after January 2008 for the 24 month ahead forecast and after June 2006 for the 30 month ahead forecast respectively.

Comparing Figures 3a-3b and Figures 4a-4b, we find that the instability in the coefficient estimates of non-US/non-China global money growth is relatively smaller than that of Chinese money growth before July 2006. The largest changes in the coefficient estimates of the global money growth are in the period between July 2006 and early 2010, 
whereas the largest changes in the coefficient estimates of Chinese money growth are between late 2009 and early 2011 in the period after China's money stock surpassed US money stock in August 2009. The coefficient estimates of Chinese (non-US/non-China global) money growth are mostly negative (positive) before January 2009 and vice versa after early 2009, for the 12 month ahead forecast. At the same point of time, the two coefficient estimates move mostly in the opposite direction for the same 18, 24, and 30-month ahead forecast respectively. These results confirm that effects of China's money growth $\left(\beta_{2}\right)$ are different from that of non-US/non-China global money growth $\left(\beta_{4}\right)$ on the trade-weighted US dollar exchange index over time.

\subsection{Terms of trade}

We now consider the impact of China's growth in liquidity on the US terms of trade index, TOT, given by the ratio of the US dollar price of US exports to the US dollar price of US imports. The terms of trade is interpreted as the amount of import goods an economy can purchase per unit of export goods. In Equation (1) TWI is replaced by TOT. The new equation is estimated in a rolling sample analysis.

Figures $5 \mathrm{a}$ and $5 \mathrm{~b}$ show changes in the coefficients of China's M2 in the forecast of the US terms of trade. Rolling sample analysis indicates changes over time in the influence of variables in forecasting the US terms of trade index at all horizons. In forecasting US terms of trade, China's M2 growth forecast a significantly lower terms of trade value 30 months later throughout the sample. The fall in terms of trade 30 months later is greatest from July 2007 onwards. The effect of China's M2 growth on terms of trade changes sign over the sample at the forecast horizons of 12, 18 and 24 months ahead. However, China's M2 growth forecast a significantly higher value for terms of trade 18 months later from May 2007. In Figure 5b, it is apparent that the largest impacts of China's liquidity on terms of trade, and the 
greatest divergence of the effect of China's liquidity on the future value of the terms of trade across forecast horizons, occur after April 2007, especially so after October 2009.

\section{Robustness}

To establish the robustness results of our analysis, we utilize a 24-month moving average of annual growth rates of monthly data for all the variables and also investigate the implication of constructing the growth rate in the non-China/non-US global monetary aggregate in a different way. The longer moving average used with time-series data is expected to make the short-term fluctuations smoother and highlight longer-term trends or cycles more. The estimation of equation (1) for the sticky price monetary model with variables representing 24 moving average is reported in column (1) of Table 4. In column (1) the non-China/non-US global monetary aggregate is based on the growth rate of a broad monthly monetary aggregate constructed for the Euro area, UK, Japan, and Brazil, Russia and India. The estimate of equation (1) in column 1 , Table 4 is very similar to the estimate of equation (1) in column 1, Table 2. In results not shown, the MSFE is significantly lower for the monetary model with sticky prices than for the random walk model with 24-month moving average of annual growth rates of monthly data.

We now construct the non-China/non-US global monetary aggregate differently. Following D’Agostino and Surico (2009) by analogy, the (non-China/non-US) global money growth is defined as the simple mean of the annual growth rates of monthly money stocks including M4 for the UK, M2 for Japan, M2 for Canada, and M2 for the Euro area. This measure of the (non-China/non-US) global money growth is different from that used throughout the paper in that the group of countries is different and the growth rate of global liquidity is the simple mean of individual economy's monetary aggregate growth rates. Column (2) of Table 4 shows that the coefficient estimates of all variables in forecasting 
trade weighted US dollar index 25-month ahead are quantitatively and qualitatively similar to that in column (1) of Table 2. The coefficient estimate of the non-US/non-China global money growth variable is statistically significant at the ten percent level. In results not shown, the MSFE is significantly lower for the monetary model with sticky prices than for the random walk model when the simple mean of the annual growth rates of monthly money stocks is used as the measure of non-China/non-US global money growth.

\section{Conclusion}

Rossi (2013) observes in an extensive review of the literature on exchange rate predictability, that overall, empirical work does not find that customary predictors such as differentials in interest rate, inflation and output variables do a very good job at out-ofsample prediction of the exchange rate. ${ }^{11}$ We have found some success with using traditional predictors, but at global level, in forecasting the US dollar exchange rate one to two and a half years ahead. Differentials between non-US global and US values for inflation, output, and interest rates are highly statistically significant in forecasting the US dollar exchange rate. China's liquidity does have a distinct, significant and changing influence on the US dollar exchange rate.

We develop out-of-sample forecasts of the US dollar exchange rate value using US and non-US global data on inflation, output, interest rates, and liquidity on the US, China and non-US/non-China liquidity. Model forecasts of all the monetary models estimated significantly outperform a random walk forecast in terms of MSFE at horizons over 12 months to 30 months years ahead. The best forecast is from the monetary model with sticky

\footnotetext{
${ }^{11}$ Rossi (2013) notes (contested) evidence that the monetary model at very long horizons and uncovered interest rate models at short horizons have some success at out-of-sample prediction of the exchange rate, and that it is thought that models based on Taylor rule gaps and net foreign assets have more encouraging out-of-sample forecasting capability for out-of-sample prediction for exchange rates.
} 
prices for the US dollar exchange rate at 25 months ahead. Rolling sample analysis indicates changes over time in the influence of variables in forecasting the US dollar.

It is difficult to tie results on the changing sign of the coefficient for the effect of China's liquidity growth on the US dollar exchange rate to the timing of China's changing exchange rate policy. The estimates of the coefficient of the effect of China's liquidity growth on the US dollar exchange rate change over time for each forecast horizon with the greatest divergence of estimates across forecast horizons occurring with forecasts made from late 2009 to early 2011. Post global financial crisis, increases in the growth rate in China's M2 forecast a significantly higher value for the US dollar 12 months and 18 months later and significantly lower values for the US dollar 24 and 30 months later. The finding that the largest effects of China's M2 growth on the US dollar are post global financial crisis is consistent with the argument by Fratzscher and Mehl (2014) that the renminbi as a key source of currency movements in Asia has been most evident since the global financial crisis. 


\section{References}

Aizenman, J., Chinn, M., Hutchison, M., 2009. Understanding Global Liquidity in a Volatile World. Review of International Economics 17, 651-654.

Beckmann, J., Belke, A., Czudaj, R., 2014. Does global liquidity drive commodity prices? Journal of Banking and Finance 48, 224-234.

Belke, A., Orth, W., Setzer, R., 2010. Liquidity and the dynamic pattern of asset price adjustment: A global view. Journal of Banking and Finance 34, 1933-1945.

Bilson, J.F.O., 1978. Rational expectations and the exchange rate, in: J. Frenkel and H. Johnson, eds., The economics of exchange rates (Addison-Wesley Press, Reading).

Bilson, John F.O., 1979. The deutsche mark/dollar rate -- A monetary analysis, in: Karl Brunner and Allan H. Meltzer, eds., Policies for employment, prices and exchange rates, Carnegie-Rochester Conference 11 (North-Holland Publishing Company, Amsterdam).

Bruno, V., Shin, H. S., 2015. Capital flows and the risk-taking channel of monetary policy. Journal of Monetary Economics 71, 119-132.

Cheung, Y.-W., Chinn, M.D., Qian, X., 2015. China-US trade flow behavior: the implications of alternative exchange rate measures and trade classifications. Forthcoming Review of World Economy. DOI 10.1007/s10290-015-0232-y.

Chinn, M.D., 2009. The symposium on 'China's impact on the global economy'. Pacific Economic Review 14 (3), 342-345.

Chinn, M.D., 2012. Macro Approaches to Foreign Exchange Determination. Chapter 2 Handbook of Exchange Rates, J. James, I.W. Marsh, L. Sarno (Eds.), John Wiley \& Sons Inc., 45-71.

Chinn, M.D., Moore, M.J., 2011. Order flow and the monetary model of exchange rates: evidence from a novel data set. Journal of Money, Credit, and Banking 43, 1599-1624.

Clark, T. E., McCracken, M.W. (2015). Nested forecast model comparisons: A new approach to testing equal accuracy. Journal of Econometrics 186, 160-177.

D’Agostino, A., Surico, P., 2009. Does global liquidity help to forecast US inflation? Journal of Money, Credit and Banking 41, 479-489.

Darvas, Z., 2012. Real effective exchange rates for 178 countries: a new database. Bruegel Working Paper 2012/06. Available at:

http://www.bruegel.org/publications/publicationdetail/publication/716-real-effectiveexchange-rates-for-178-countries-a-new-database/.

Dekle, R., Ungor, M., 2013. The real exchange rate and the structural transformation (s) of China and the US. International Economic Journal 27, 303-319. 
Diebold, F. X., Mariano, R.S., 1995. Comparing predictive accuracy. Journal of Business and Economic Statistics 13, 253-263.

Dornbusch, R., 1976. Expectations and exchange rate dynamics. Journal of Political Economy 84, 1161-1176.

Engel, C., Mark, N.C., West, K.D., 2015. Factor model forecasts of exchange rates. Econometric Reviews, 34, 32-55.

Frankel, J. A., 1979. On the mark: A theory of floating exchange rates based on real interest differentials. American Economic Review 69, 610-622.

Frankel, J. A., 2009. New estimation of China's exchange rate regime. Pacific Economic Review 14 (3), 346-360.

Fratzscher, M., Mehl, A., 2014. China's dominance hypothesis and the emergence of a tripolar global currency system, Economic Journal 124, 1343-1370.

Frenkel, J.A., 1976. A monetary approach to the exchange rate: Doctrinal aspects and empirical evidence. Scandinavian Journal of Economics 78, 200--224.

Giacomini, R., Rossi, B., 2010. Forecast comparisons in unstable environments. Journal of Applied Econometrics 25, 595-620.

Goldberg, L.S., 2011. The international role of the dollar: Does it matter if this changes? FRB of New York Staff Report 522.

Granville, B., Mallick, S., Zeng, N., 2011. Chinese exchange rate and price effects on G3 import prices. Journal of Asian Economics, 22 (6), 427-440.

Grossman, V., Mack, A., Martinez-Garcia, E., 2013. Database of global economic indicators (DGEI): a methodological note. Federal Reserve Bank of Dallas Globalization and Monetary Policy Institute Working Paper 166.

Holt, C.C., 2004. Forecasting seasonals and trends by exponentially weighted moving averages. International journal of forecasting, 20, 5-10.

Lo Duca, M., Nicoletti, G., Vidal Martinez, A., 2014. Global corporate bond issuance: what role for US quantitative easing? ECB Working Paper Series, no 1649.

Loretan, M., 2005. Indexes of the foreign exchange value of the dollar. Federal Reserve Bulletin 91.

Maasoumi, E., Bulut, L., 2013. Predictability and specification in models of exchange rate determination. In Recent Advances and Future Directions in Causality, Prediction, and Specification Analysis, 411-436. Springer New York.

McCauley, R.N., McGuire, P., Sushko, V., 2015. Global dollar credit: links to US monetary policy and leverage. Bank for International Settlements, BIS Working Paper No 483. 
Meese, R.A., Rogoff, K., 1983. Empirical Exchange Rate Models of the Seventies: Do they fit out of sample? Journal of International Economics 14, 3-24.

Ratti, R.A., Vespignani, J.L., 2015. Commodity prices and BRIC and G3 liquidity: A SFAVEC approach. Journal of Banking \& Finance 53, 18-33.

Rossi, B., 2013. Exchange rate predictability. Journal of Economic Literature 51, 1063-1119.

Sarno, L., Taylor, M.P., 2002. The economics of exchange rates. Cambridge University Press.

Stock, J.H., Watson, M.W., 2007. Why has US inflation become harder to forecast? Journal of Money, Credit and banking 39, 3-33.

Thomas, C.P., Marquez, J., Fahle, S., 2009. Measures of international relative prices for China and the USA. Pacific Economic Review 14 (3), 376-397.

Whalley, J., Wang, L., 2011. The impacts of Renminbi appreciation on trade flows and reserve accumulation in a monetary trade model, Economic Modelling 28, 614-621. 


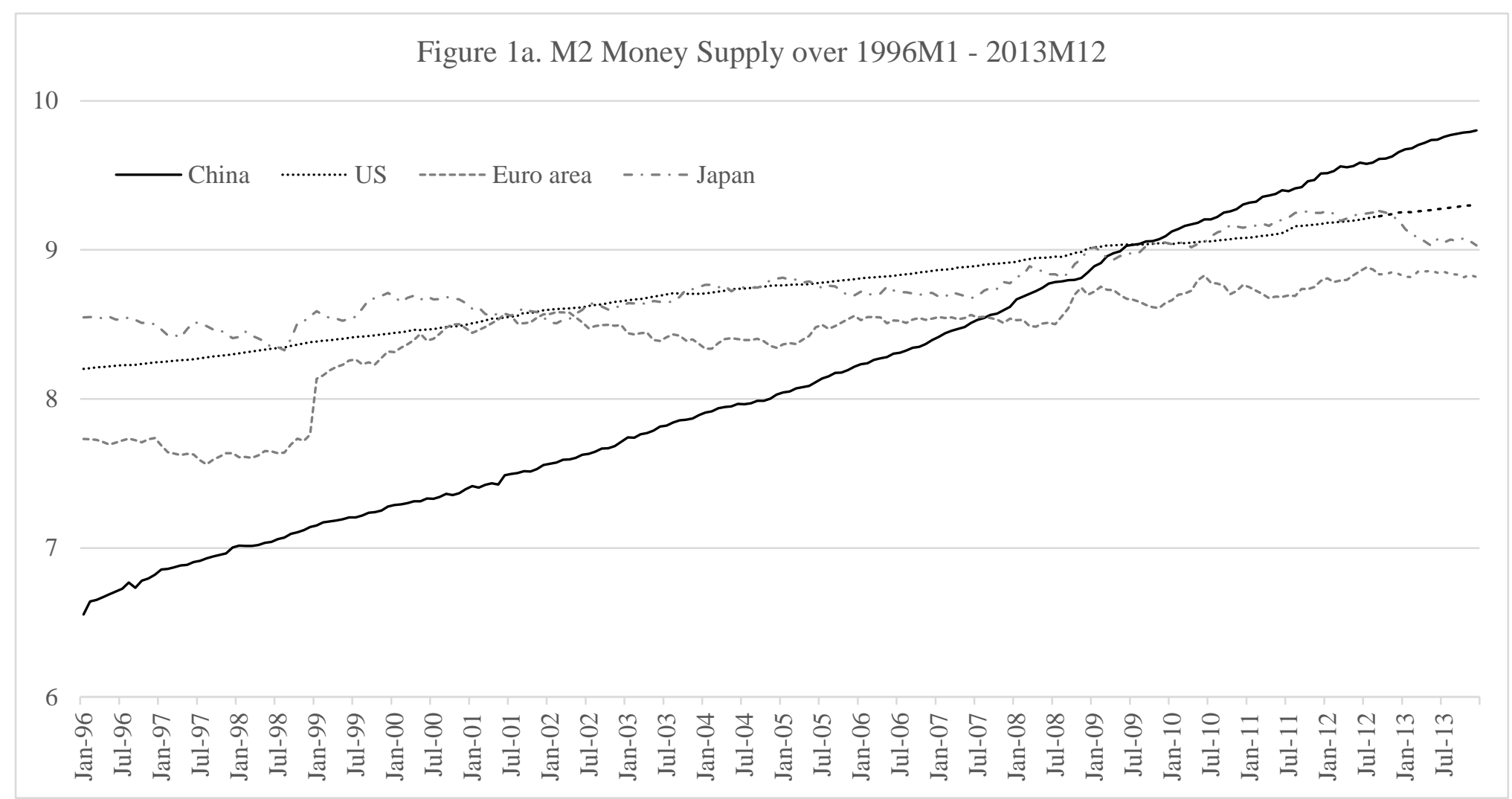

Notes: Figure 1a presents the log of M2 money supplies expressed in U.S. dollars in China, U.S., Euro area, and Japan over 1996M1-2013M12. 
Figure 1b. US TWI and Chinese Yuan to USD

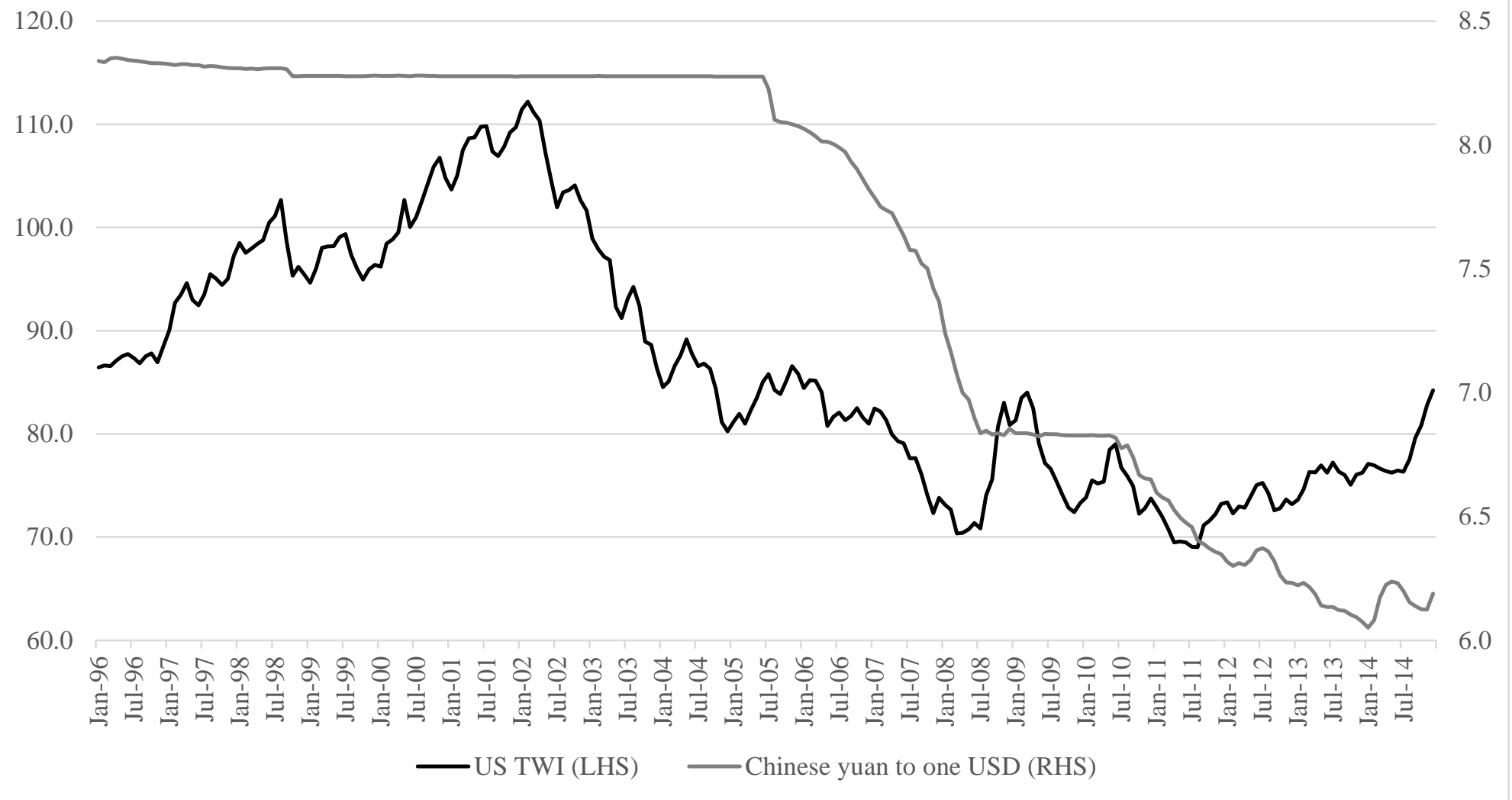

Notes: Figure 1b shows nominal US TWI to major currencies and the Chinese yuan exchange rate in terms of US dollars from 1996M1 2014M12. 
Figure 2. The Annual Growth Rate of Monthly Data between 1997M1 - 2013M12.

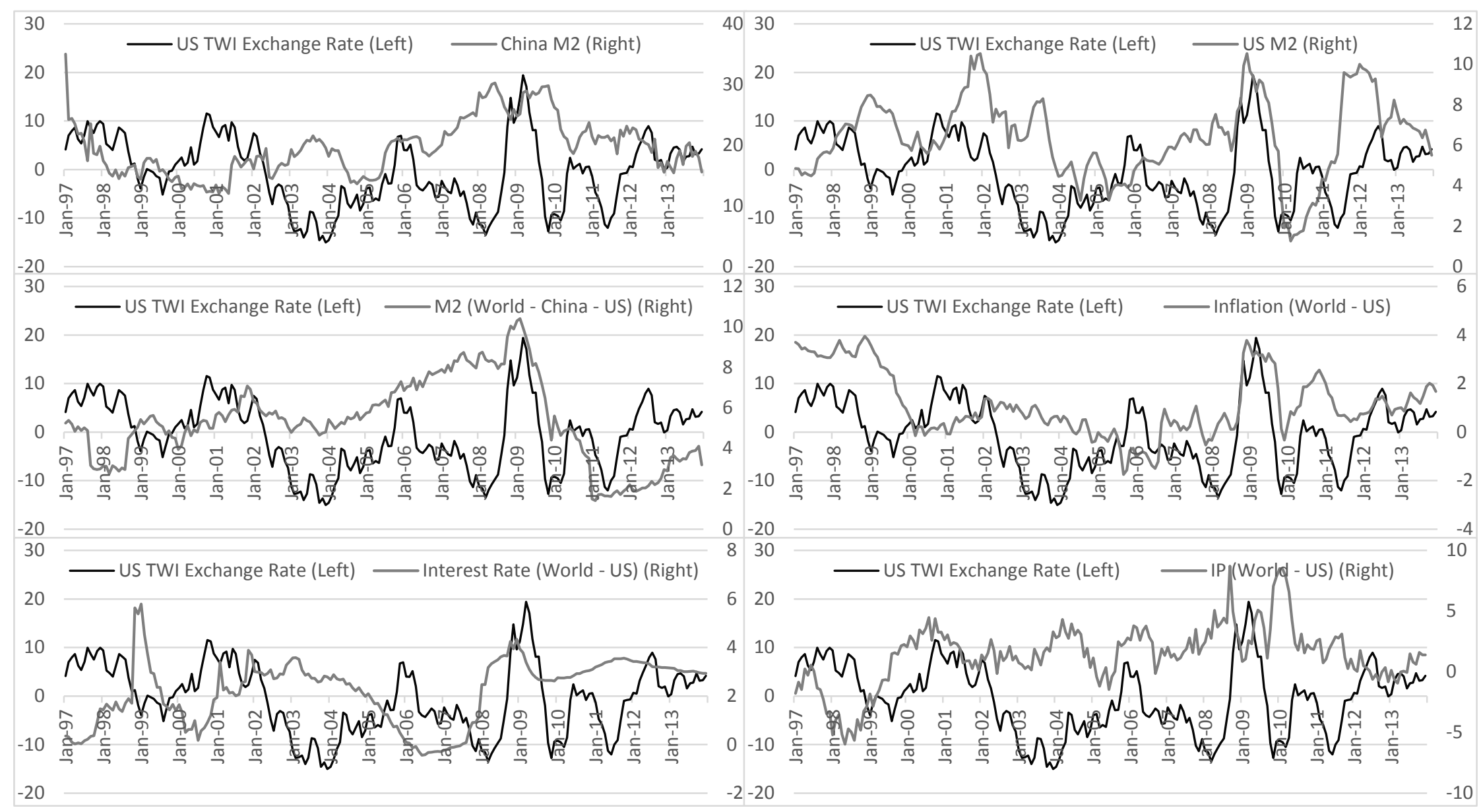


Figure 3a. Coefficient estimates of Chinese money growth at the 12, 18, 24 and 30 month ahead forecast horizons of nominal US-TWI exchange rate
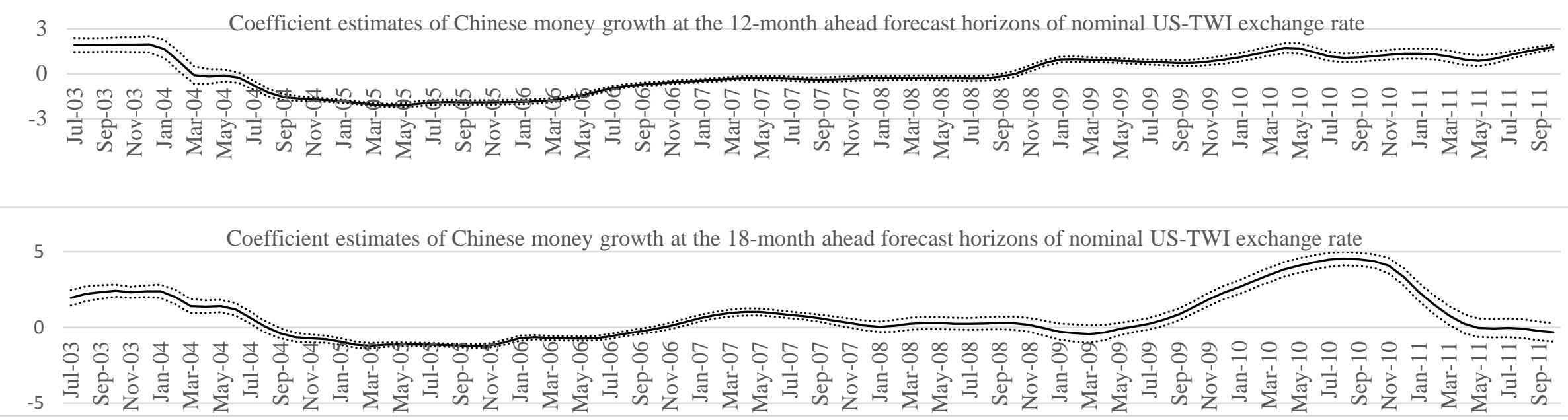

5 Coefficient estimates of Chinese money growth at the 24-month ahead forecast horizons of nominal US-TWI exchange rate

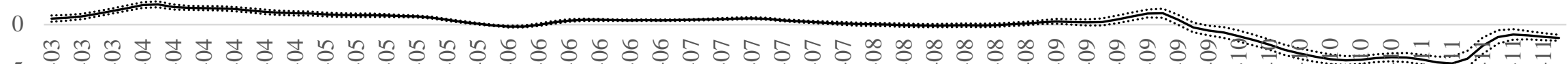

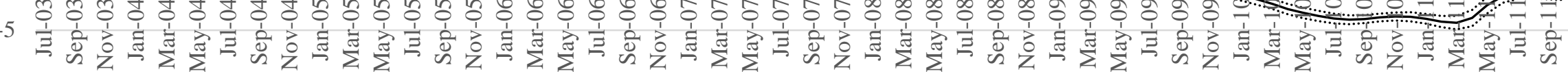

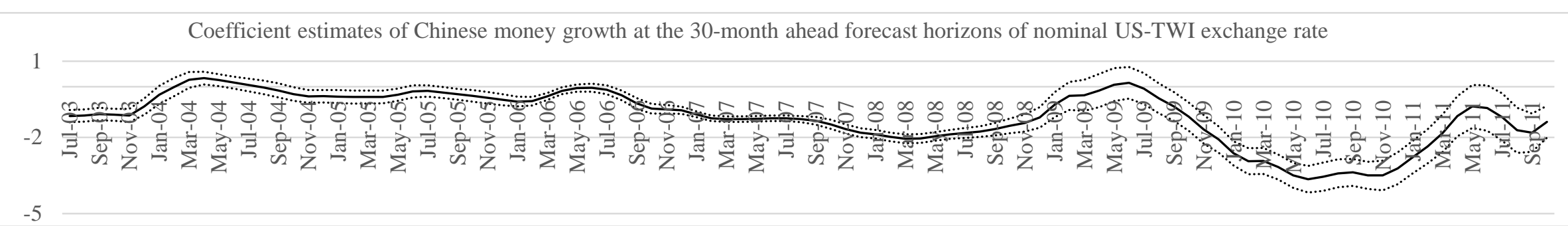

Notes: The figure shows the parameter instability and the role of money growth. It illustrates the coefficient estimates of money growth at the h-month ahead forecast horizons of nominal US-TWI exchange rate with one-standard error bands. We utilize the rolling sample with a 55-month window that allows for the forecast starting in July 2005. 


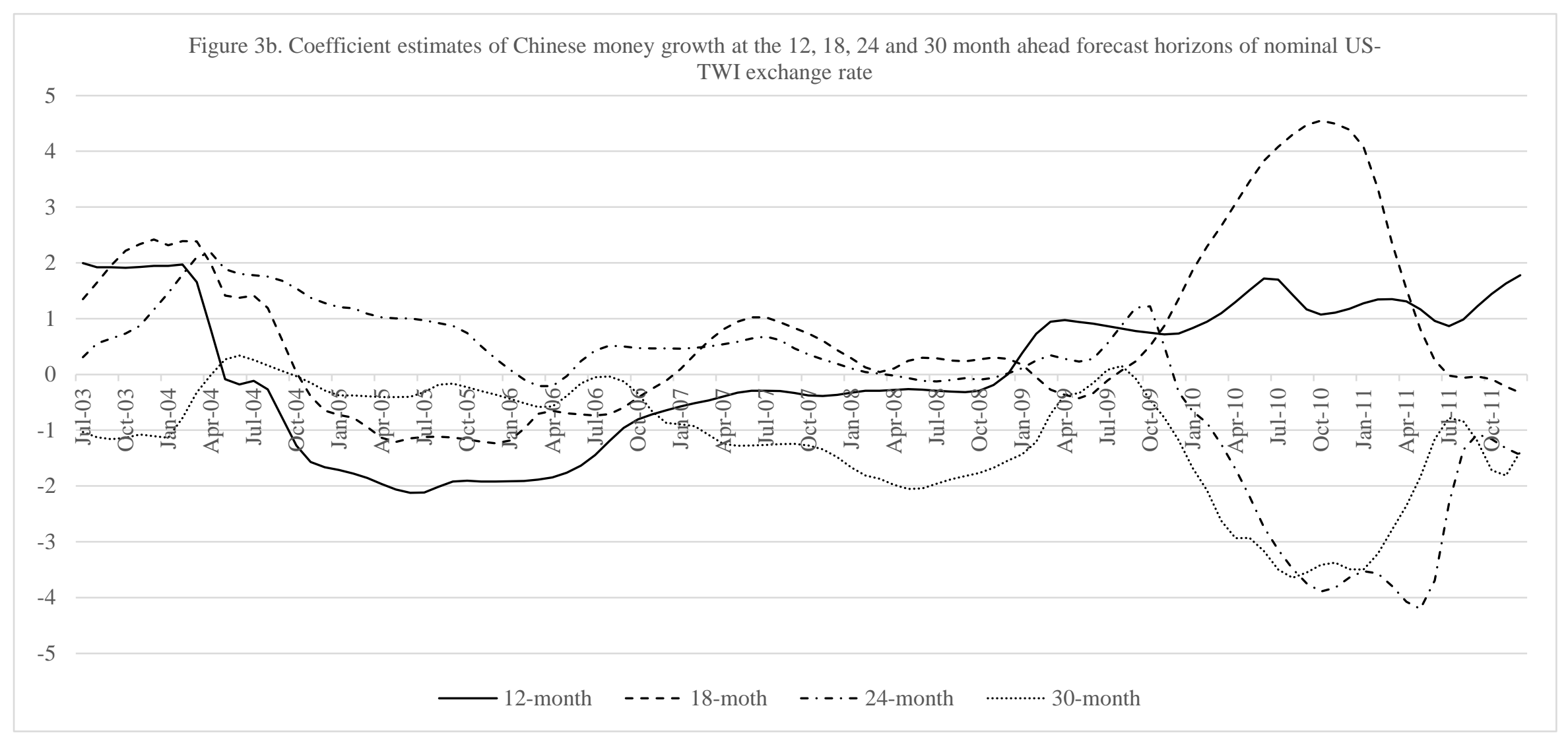

Notes: The figure shows the parameter instability and the role of money growth. It illustrates the coefficient estimates of money growth at the h-month ahead forecast horizons of nominal US-TWI exchange rate with one-standard error bands. We utilize the rolling sample with a 55-month window that allows for the forecast starting in July 2005. 
Figure 4a. Coefficient estimates of non-US/non-China global money growth at the 12, 18, 24 and 30 month ahead forecast horizons of nominal US-TWI exchange rate 4

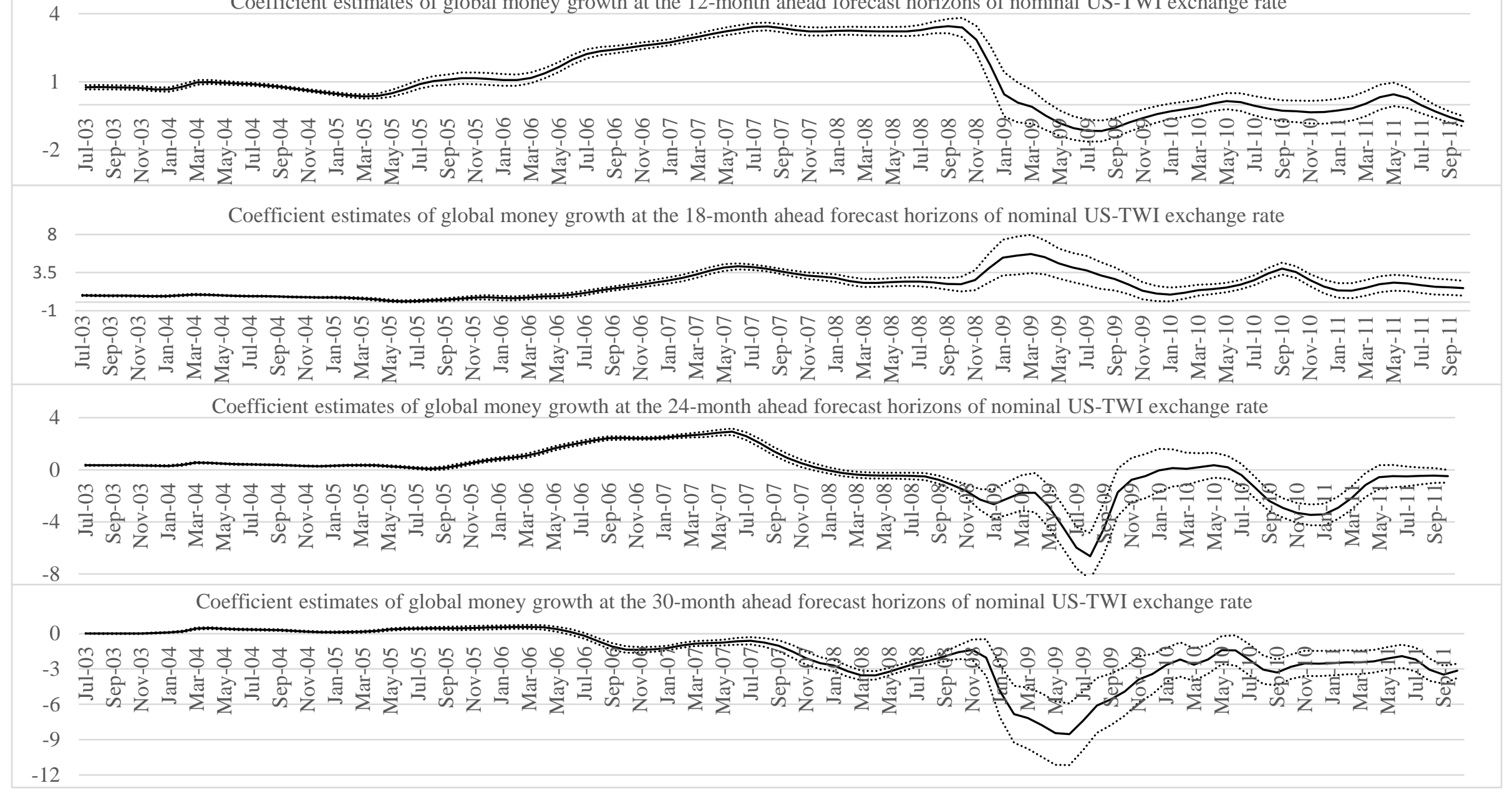

Notes: The figure shows the parameter instability and the role of non-US/non-China money growth. It illustrates the coefficient estimates of non-US/non-China global money growth at the h-month ahead forecast horizons of nominal US-TWI exchange rate with one-standard error bands. We utilize the rolling sample with a 55-month window that allows for the forecast starting in July 2005. 


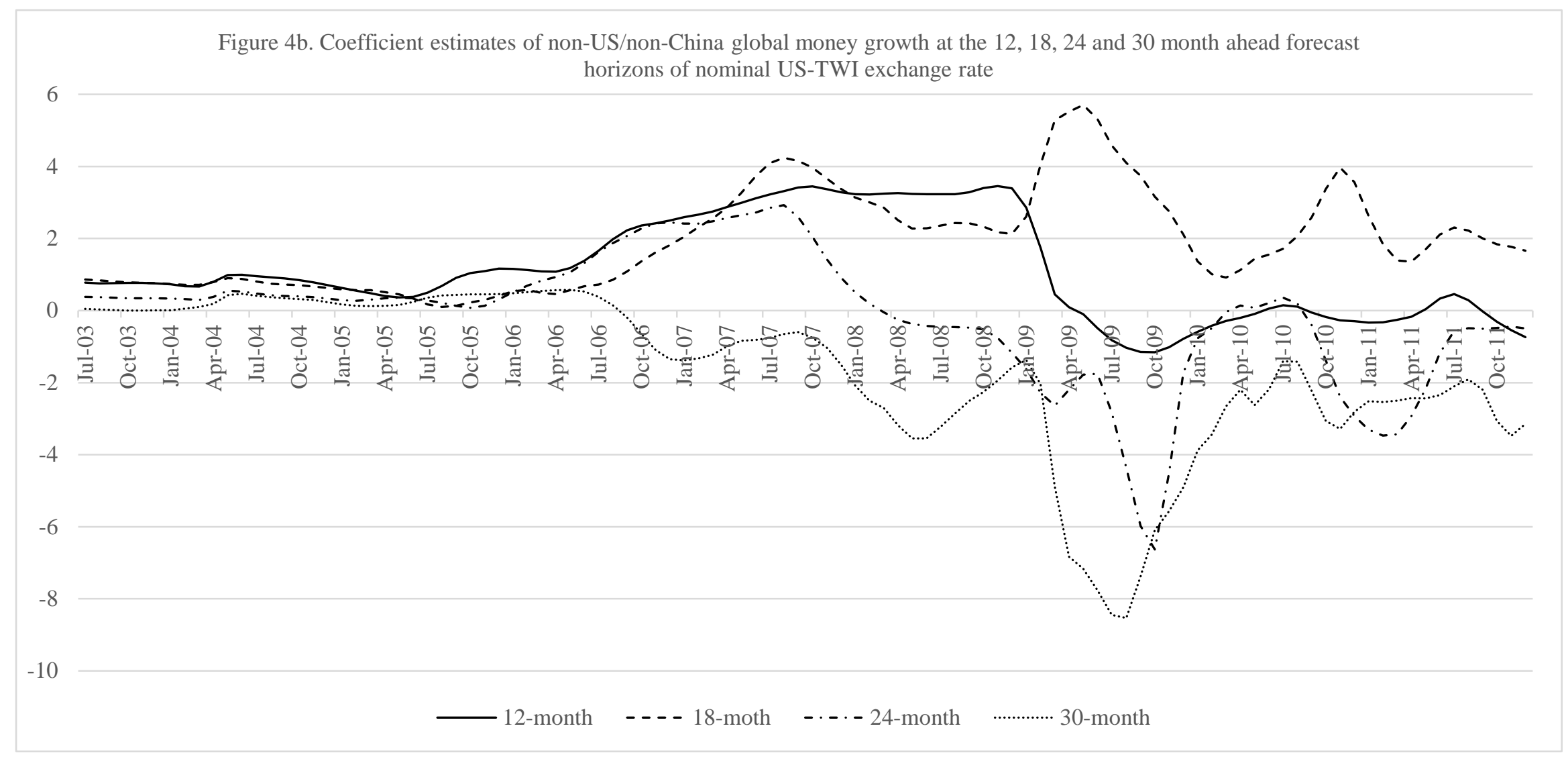

Notes: The figure shows the parameter instability and the role of non-US/non-China global money growth. It illustrates the coefficient estimates of non-US/non-China global money growth at the h-month ahead forecast horizons of nominal US-TWI exchange rate with one-standard error bands. We utilize the rolling sample with a 55-month window that allows for the forecast starting in July 2005. 
Figure 5a. Coefficient estimates of Chinese money growth at the 12, 18, 24 and 30 month ahead forecast horizons of term of trade

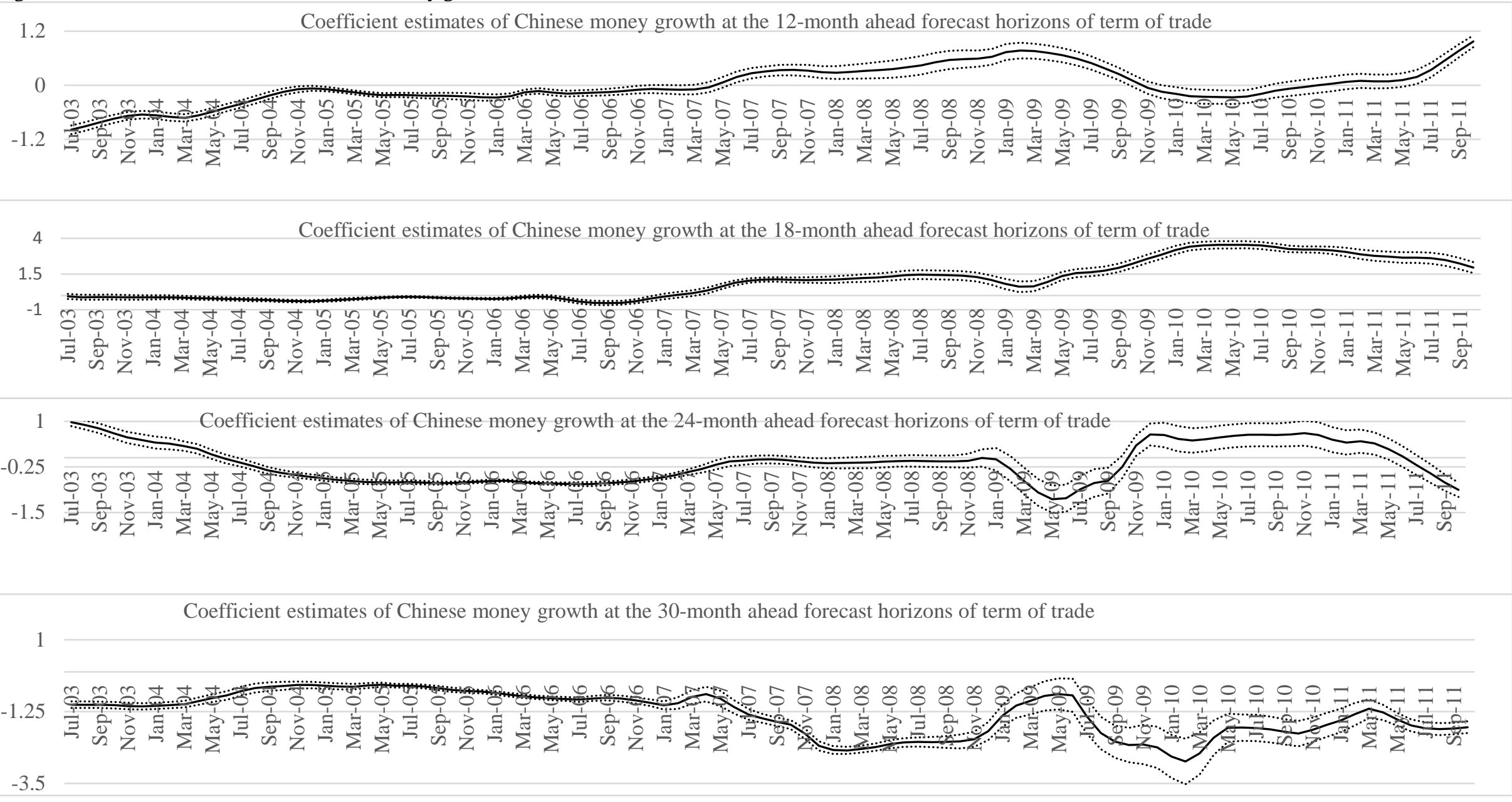

Notes: The figure shows the parameter instability and the role of money growth. It illustrates the coefficient estimates of money growth at the h-month ahead forecast horizons of term of trade with one-standard error bands. We utilize the rolling sample with a 55-month window that allows for the forecast starting in July 2005. 
Figure 5b. Coefficient estimates of Chinese money growth at the 12, 18, 24 and 30 month ahead forecast horizons of term of trade

4

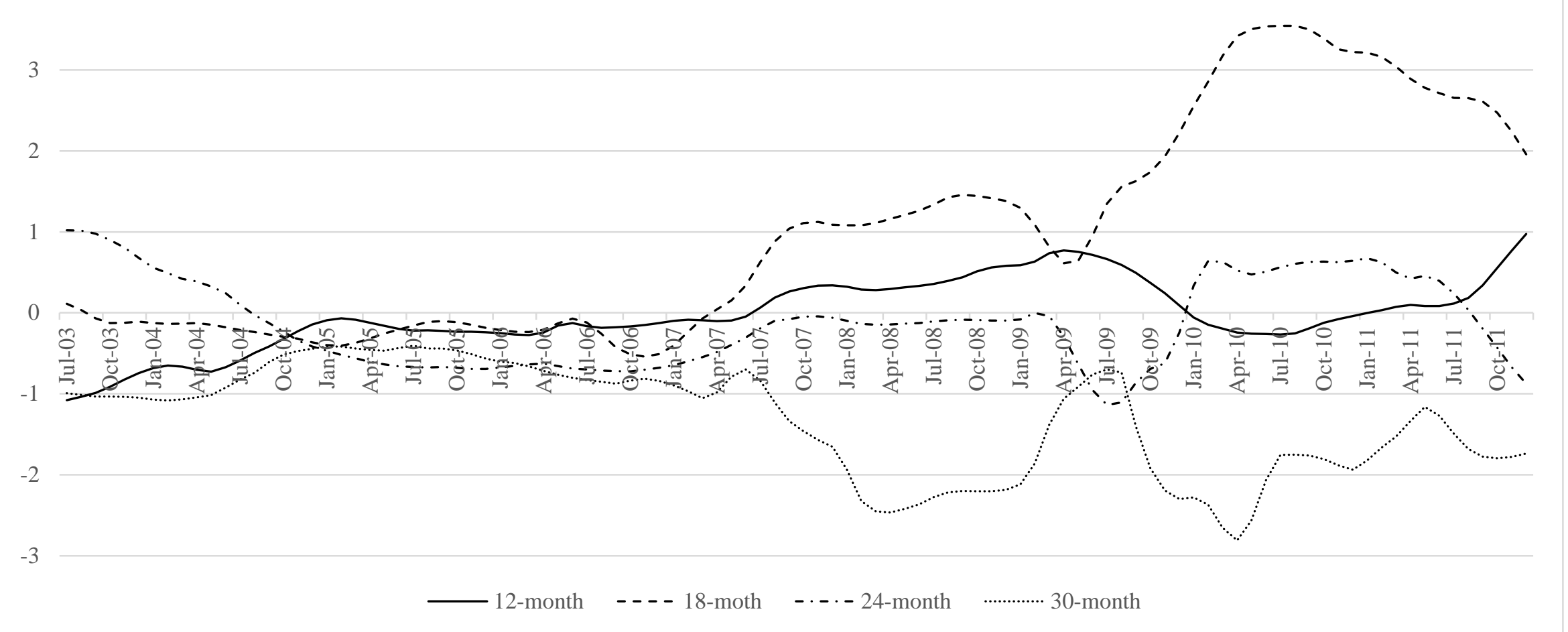

Notes: The figure shows the parameter instability and the role of money growth. It illustrates the coefficient estimates of money growth at the h-month ahead forecast horizons of term of trade with one-standard error bands. We utilize the rolling sample with a 55-month window that allows for the forecast starting in July 2005. 
Table 1. The mean square forecast error (MSFE) of the estimation for different models at different forecasting horizons

\begin{tabular}{|c|c|c|c|c|c|c|c|c|c|c|c|c|}
\hline Horizon & 12 & 14 & 16 & 18 & 20 & 22 & 24 & 25 & 26 & 28 & 30 & 36 \\
\hline MSFE $^{\text {Sticky }}$ & 14.555 & 15.492 & 15.522 & 14.303 & 11.660 & 8.216 & 5.474 & 4.884 & 4.956 & 6.771 & 9.729 & 13.171 \\
\hline $\mathrm{MSFE}^{\mathrm{RW}}$ & 49.413 & 57.088 & 63.224 & 68.569 & 73.452 & 77.819 & 81.173 & 82.371 & 83.205 & 83.380 & 81.352 & 65.868 \\
\hline $\mathrm{MSFE}^{\text {Sticky }} / \mathrm{MSFE}^{\mathrm{RW}}$ & 0.295 & 0.271 & 0.246 & 0.209 & 0.159 & 0.106 & 0.067 & 0.059 & 0.060 & 0.081 & 0.120 & 0.200 \\
\hline DM-Statistics & $2.83 * * *$ & $3.28 * * *$ & $3.99 * * *$ & $4.64 * * *$ & $4.84 * * *$ & $4.87 * * *$ & $4.94 * * *$ & $4.85 * * *$ & $4.57 * * *$ & $3.62 * * *$ & $2.72 * * *$ & 1.59 \\
\hline MSFE $^{\text {Flexible-1 }}$ & 19.542 & 18.006 & 16.013 & 14.255 & 13.057 & 12.587 & 12.954 & 13.488 & 14.222 & 15.865 & 17.140 & 13.997 \\
\hline $\mathrm{MSFE}^{\text {Flexible-1}} / \mathrm{MSFE}^{\mathrm{RW}}$ & 0.395 & 0.315 & 0.253 & 0.208 & 0.178 & 0.162 & 0.160 & 0.164 & 0.171 & 0.190 & 0.211 & 0.213 \\
\hline DM-Statistics & $2.87 * * *$ & $3.32 * * *$ & $4.00 * * *$ & $4.63 * * *$ & $4.63 * * *$ & $4.18^{* * *}$ & $3.67 * * *$ & $3.41^{* * *}$ & $3.14 * * *$ & $2.61^{* * *}$ & $2.17 * *$ & 1.54 \\
\hline MSFE $^{\text {Flexible-2 }}$ & 19.544 & 18.170 & 16.305 & 14.575 & 13.324 & 12.784 & 13.078 & 13.574 & 14.269 & 15.832 & 17.039 & 14.367 \\
\hline $\mathrm{MSFE}^{\text {Flexible-2}^{2}} / \mathrm{MSFE}^{\mathrm{RW}}$ & 0.396 & 0.318 & 0.258 & 0.213 & 0.181 & 0.164 & 0.161 & 0.165 & 0.171 & 0.190 & 0.209 & 0.218 \\
\hline DM-Statistics & $2.92 * * *$ & $3.45^{* * *}$ & $4.30 * * *$ & $5.03 * * *$ & $4.84^{* * *}$ & $4.21 * * *$ & $3.63 * * *$ & $3.36 * * *$ & $3.09 * * *$ & $2.58 * * *$ & $2.15^{* *}$ & 1.53 \\
\hline
\end{tabular}

Notes: Mean square forecast error (MSFE) are reported for different versions of equation (1) from rolling sample analysis. "RW" refers to random walk model. "Stickey" refers to the monetary model with sticky prices (with interest rate, inflation, output, and money stocks as forecasting variables). "Flexible 1" is the monetary model with flexible prices and with interest rate, output, and money stocks as forecasting variables. "Flexible 2" is the monetary model with flexible prices and with output and money stocks as forecasting variables. Estimates of the nominal US dollar exchange rate at out-of-sample forecast horizons from 12 to 36 months. All the variables in the underlying regressions are 12-month moving average of annual growth rates of monthly data. The DM-statistic is proposed by Diebold and Mariano (1995). The ***, **, and * denote the significant levels at $1 \%, 5 \%$, and $15 \%$ respectively. 
Table 2. Estimates of the nominal trade weighted US dollar exchange rate index at $\mathrm{h}=25$

\begin{tabular}{|c|c|c|c|c|c|c|c|c|c|c|c|c|c|c|c|c|}
\hline \multicolumn{17}{|c|}{ Dependent variable: $\mathrm{TWI}_{\mathrm{t}+25}$} \\
\hline & \multicolumn{2}{|c|}{ (1) } & \multicolumn{2}{|c|}{$(2)$} & \multicolumn{2}{|c|}{ (3) } & \multicolumn{2}{|c|}{$(4)$} & \multicolumn{2}{|c|}{ (5) } & \multicolumn{2}{|c|}{ (6) } & \multicolumn{2}{|c|}{ (7) } & \multicolumn{2}{|c|}{ (8) } \\
\hline Constant & $\begin{array}{r}6.995 \\
(5.07)\end{array}$ & $* * *$ & $\begin{array}{l}4.470 \\
(3.96)\end{array}$ & $* * *$ & $\begin{array}{r}-1.746 \\
(2.48)\end{array}$ & $* *$ & $\begin{array}{l}5.573 \\
(4.97)\end{array}$ & $* * *$ & $\begin{array}{l}9.646 \\
(7.63)\end{array}$ & $* * *$ & $\begin{array}{l}-4.729 \\
(2.08)\end{array}$ & $* *$ & $\begin{array}{l}-3.865 \\
(1.93)\end{array}$ & $*$ & $\begin{array}{r}-3.426 \\
(1.73)\end{array}$ & $*$ \\
\hline $\mathrm{TWI}_{\mathrm{t}}$ & $\begin{array}{r}-0.625 \\
(13.81)\end{array}$ & $* * *$ & $\begin{array}{r}-0.555 \\
(13.58)\end{array}$ & $* * *$ & $\begin{array}{r}-0.667 \\
(16.10)\end{array}$ & $* * *$ & $\begin{array}{r}-0.787 \\
(17.75)\end{array}$ & $* * *$ & $\begin{array}{r}-0.661 \\
(14.23)\end{array}$ & $* * *$ & $\begin{array}{r}-0.329 \\
(4.76)\end{array}$ & $* * *$ & $\begin{array}{l}-0.226 \\
(3.59)\end{array}$ & $* * *$ & $\begin{array}{r}-0.210 \\
(3.38)\end{array}$ & $* * *$ \\
\hline Inflation $_{\mathrm{t}}$ & $\begin{array}{r}6.411 \\
(16.18)\end{array}$ & $* * *$ & $\begin{array}{r}5.643 \\
(15.95)\end{array}$ & $* * *$ & $\begin{array}{r}5.581 \\
(13.84)\end{array}$ & $* * *$ & $\begin{array}{r}7.637 \\
(21.10)\end{array}$ & $* * *$ & $\begin{array}{r}7.341 \\
(21.90)\end{array}$ & $* * *$ & & & & & & \\
\hline Interest Rate $_{\mathrm{t}}$ & $\begin{array}{r}-3.969 \\
(14.10)\end{array}$ & $* * *$ & $\begin{array}{r}-3.617 \\
(13.22)\end{array}$ & $* * *$ & $\begin{array}{r}-4.077 \\
(13.74)\end{array}$ & $* * *$ & $\begin{array}{r}-4.936 \\
(17.71)\end{array}$ & $* * *$ & $\begin{array}{r}-4.394 \\
(16.09)\end{array}$ & $* * *$ & & & $\begin{array}{l}-0.407 \\
(1.40)\end{array}$ & & & \\
\hline Output $_{t}$ & $\begin{array}{r}0.203 \\
(1.21)\end{array}$ & & $\begin{array}{r}-0.225 \\
(1.85)\end{array}$ & * & $\begin{array}{r}-0.005 \\
(0.04)\end{array}$ & & $\begin{array}{r}0.775 \\
(4.63)\end{array}$ & $* * *$ & $\begin{array}{r}0.403 \\
(2.41)\end{array}$ & $* * *$ & & & $\begin{array}{r}-1.525 \\
(7.12)\end{array}$ & $* * *$ & $\begin{array}{r}-1.533 \\
(7.14)\end{array}$ & $* * *$ \\
\hline $\mathrm{M} 2_{\mathrm{t}}^{\text {China }}$ & $\begin{array}{l}-0.154 \\
(2.43)\end{array}$ & $* *$ & & & & & $\begin{array}{l}-0.327 \\
(5.02)\end{array}$ & $* * *$ & $\begin{array}{r}-0.249 \\
(4.06)\end{array}$ & $* * *$ & $\begin{array}{c}0.108 \\
(1.39)\end{array}$ & & $\begin{array}{r}0.466 \\
(5.59)\end{array}$ & $* * *$ & $\begin{array}{r}0.448 \\
(5.42)\end{array}$ & $* * *$ \\
\hline $\mathrm{M} 2_{\mathrm{t}}^{\mathrm{US}}$ & $\begin{array}{l}-0.868 \\
(5.60)\end{array}$ & $* * *$ & $\begin{array}{r}-0.938 \\
(5.98)\end{array}$ & $* * *$ & & & & & $\begin{array}{r}-0.893 \\
(5.51)\end{array}$ & $* * *$ & $\begin{array}{r}-0.553 \\
(2.22)\end{array}$ & $* *$ & $\begin{array}{r}-1.130 \\
(4.42)\end{array}$ & $* * *$ & $\begin{array}{r}-1.265 \\
(5.33)\end{array}$ & $* * *$ \\
\hline $\mathrm{M} 2_{\mathrm{t}}{ }^{\mathrm{w}}-\mathrm{M} 2_{\mathrm{t}}^{\mathrm{US}}-\mathrm{M} 2_{\mathrm{t}}^{\text {China }}$ & $\begin{array}{r}0.128 \\
(3.97)\end{array}$ & $* * *$ & & & & & & & & & $\begin{array}{r}0.461 \\
(9.43)\end{array}$ & $* * *$ & $\begin{array}{r}0.435 \\
(10.10)\end{array}$ & $* * *$ & $\begin{array}{r}0.425 \\
(9.97)\end{array}$ & $* * *$ \\
\hline $\mathrm{M} 2_{\mathrm{t}}^{\mathrm{w}}-\mathrm{M} 2_{\mathrm{t}}^{\mathrm{US}}$ & & & $\begin{array}{c}0.177 \\
(4.71)\end{array}$ & $* * *$ & & & & & & & & & & & & \\
\hline $\mathrm{M} 2_{\mathrm{t}}{ }^{\mathrm{w}}$ & & & & & $\begin{array}{c}0.286 \\
(4.66)\end{array}$ & $* * *$ & & & & & & & & & & \\
\hline MSFE & 4.88 & & 5.19 & & 6.56 & & 6.42 & & 5.37 & & 18.0 & & 13.4 & & 13.5 & \\
\hline Adj. $\mathrm{R}^{2}$ & 0.84 & & 0.83 & & 0.79 & & 0.79 & & 0.83 & & 0.43 & & 0.57 & & 0.5 & \\
\hline
\end{tabular}

Notes: Estimates of equation (1) are shown with dependent variable TWI $\mathrm{T}_{\mathrm{t}+25}$, nominal trade weighted US dollar exchange rate index 25 months ahead. TWI is the nominal trade weighted US dollar exchange rate index. Inflation ${ }_{t}$, Interest Rate ${ }_{t}$ and Output $_{t}$ are differentials between non-US global and US data on inflation, interest rates, and output. $M_{t}^{\text {China }}$ is China's M2, $M_{t}^{U S}$ is the US M2, $\mathrm{M} 2_{\mathrm{t}}{ }^{\mathrm{w}}-\mathrm{M} 2_{\mathrm{t}}{ }^{\mathrm{US}}-\mathrm{M} 2_{\mathrm{t}}{ }^{\text {China }}$ is the non-China/non-US global monetary aggregate, $\mathrm{M} 2_{\mathrm{t}}{ }^{\mathrm{w}}-\mathrm{M} 2_{\mathrm{t}}{ }^{\mathrm{US}}$ is the non-US global monetary aggregate, and $\mathrm{M} 2{ }_{\mathrm{t}}{ }^{\mathrm{w}}$ is the global monetary aggregate. All variables are 12-month moving average of annual growth rates of monthly data. The $* * *$, $* *$, and * denote the significant levels at $1 \%, 5 \%$, and $15 \%$ respectively. 
Table 3. Subsample estimates of the nominal trade weighted US dollar exchange rate index

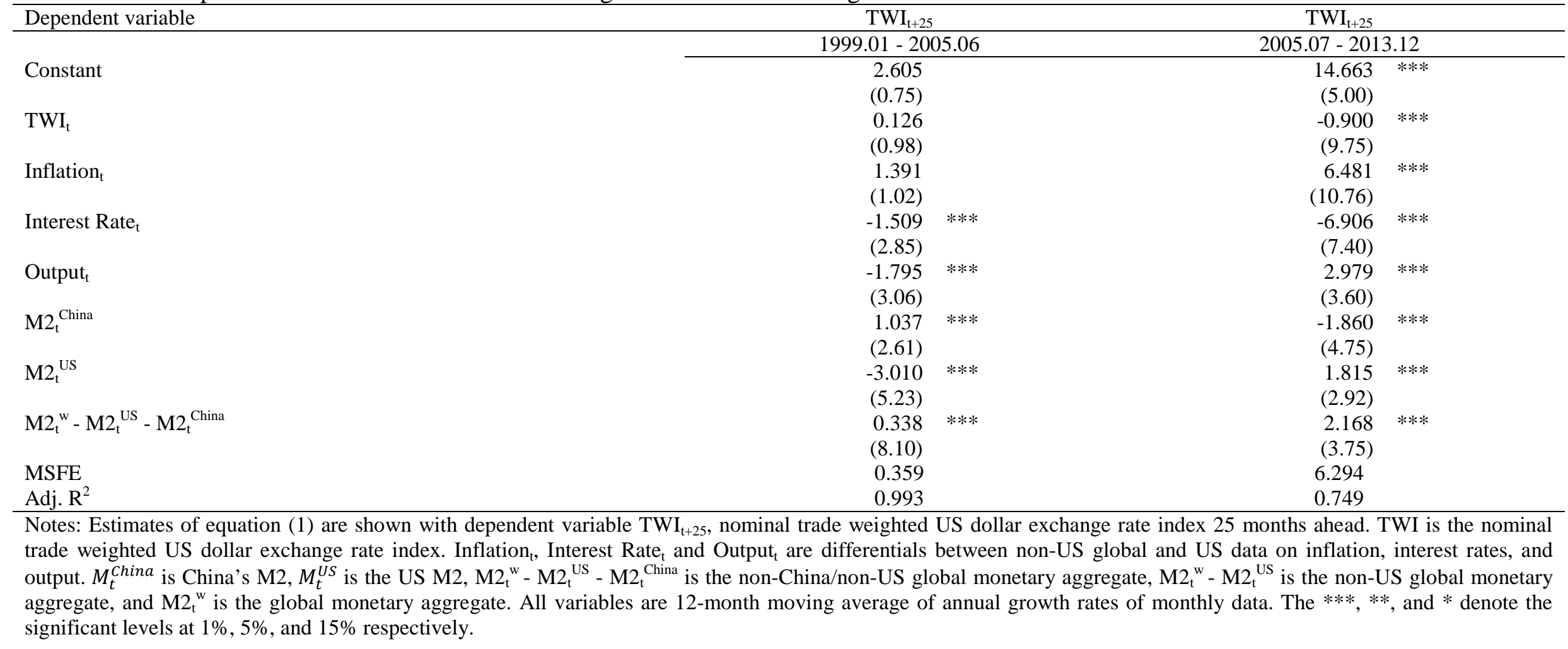


Table 4. Robust check on the estimation of the nominal trade weighted US dollar exchange rate index

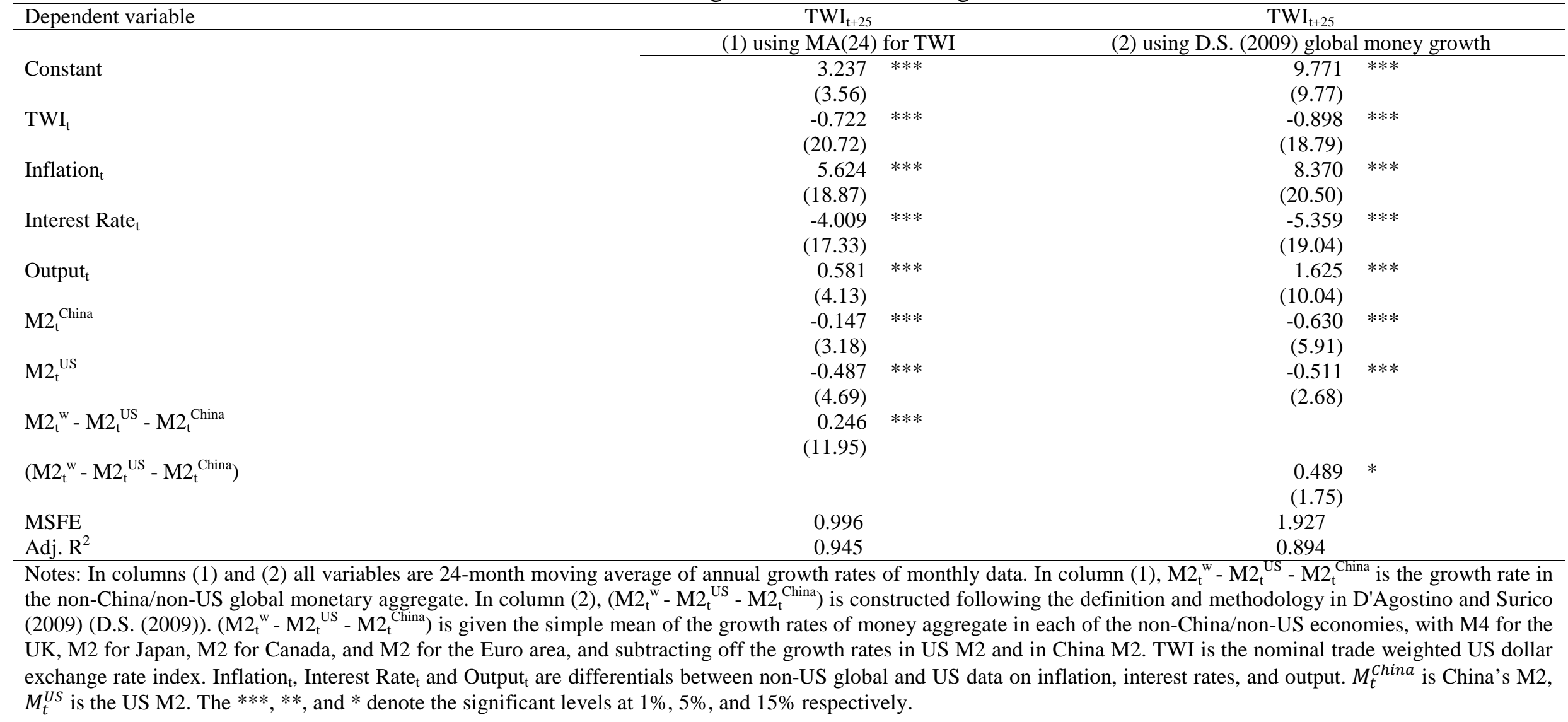

